\title{
The Steward of Book History in the Digital Age: The Struggles and Rewards of Collecting e-Books for Special Collections Institutions
}

\begin{abstract}
Collecting and preserving e-books in special collections institutions poses challenges and rewards for working professionals in the field. Although scholars of book history have spent the last decade or so including e-books in their historical overviews, reviewing e-books' connections to their physical past and speculating on their impact on the future of books, their importance in the overall timeline of book evolution has not yet made an impact on collecting guidelines. Institutions do not seem overly eager to be the first to create a permanent collection of e-books - and there may be just cause for reluctance. Not only do e-book files come with the same long-term preservation problems as any born-digital materials, they also have added complications such as a lack of standardized file format, a lack of permanence in licensing agreements, and the constant threat of content changes, just to name a few. While this paper aims to persuade special collections libraries to begin collecting e-books, it also lays out the complications standing in the way of a successful e-book collection. It starts a conversation around possible solutions for long-term preservation and patron-use challenges for e-books in special collections.
\end{abstract}

Special collections libraries have long been repositories for collecting and preserving the history of the book. From cuneiform tablets to Aldine editions to pulp paperbacks, institutions within the field work to preserve physical examples of book evolution. But collecting parameters have not yet encompassed what is, arguably, the most recent manifestation of the book: e-books. Scholars of book history have spent the last decade or so including e-books in their historical overviews, reviewing e-books' connections to their physical past and speculating on their impact on the future of books, but their role in book evolution has not yet made an impact on collecting guidelines. This paper argues for the importance and challenges collecting and preserving e-books poses for working professionals in special collections institutions.

๑ 2021 by Jessica Bigelow (CC BY-NC [https://creativecommons.org/licenses/by-nc/4.0/]). 
Institutions do not seem overly eager to be the first to create a permanent collection of e-books - and there may be just cause for reluctance. Not only do e-book files come with the same long-term preservation problems as any born-digital materials, they also have added complications such as a lack of standardized file format, a lack of permanence in licensing agreements, and the constant threat of content changes, just to name a few. While the case has not yet been effectively made for e-books as a format conducive to special collections, e-books are now part of the landscape of book production and consumption. While the format itself possesses inherent challenges differing from the discipline's long-held expectations and traditions of collecting, e-books will one day offer interesting insights into local history, individual author collections, and 20th-century book production. This article aims to persuade special collections libraries to begin collecting e-books, but it also lays out the complications standing in the way of a successful e-book collection. It starts a conversation around possible solutions for long-term preservation and patron-use challenges for e-books in special collections.

\section{Background and Literature Review}

The changes e-books are making within the book historian community are well documented. Eileen Gardiner and Ronald Musto note that "the radical dismemberment and reassociation of content in the digital realm compels us to consider [questions about books] in a new light, with a newly focused urgency...physical objects and cultural practices inevitably stand together in dynamic dialogue." The existence of e-books alters how we talk about books, not just because of the shift from physical to digital spaces, but also the rapid pace in which e-book technology supersedes itself-making e-book files much more fragile and impermanent than their print cousins. This creates the "newly focused urgency" that they expose within the book history community. The fluidity of e-books reflects and comments on the "cultural practices" of the digital age. Book historians like Gardiner and Musto have long concluded that evolutions in book production are preceded by a need in the surrounding culture, and e-books are no different. The rise of the digital age created a need for books that could interact with the greater digital environment, something that print books, no matter how many footnotes they contain, cannot do. E-book technology developed out of dialogue with that cultural need and contain interesting insights into 21st-century culture that book historians have eagerly watched unfold.

But that is not to say that all members of the book community are thrilled to welcome e-books into the fabric of book history. Michelle Levy and Tom Mole

1. Eileen Gardiner and Ronald G. Musto, "The Electronic Book," in The Book: A Global History, eds. Michael F. Suarez, S.J. and H.R. Woudhuysen (Oxford, UK: Oxford University Press, 2013), 284. 
explain that "the disquiet felt by many commentators [concerning e-books] reflects their concern that what is distinctive about the paper codex... will be lost in a digital world where the words of the book will be absolutely identical, at the level of electronic storage, with everything else."2 The words "print is dying" have been bandied around since the birth of e-books. While modern print publication has actually exploded since the birth of e-books, the death of print is a deep-rooted anxiety, particularly within the special collections and rare books community. Special collections institutions curate collections of books in various formats to preserve their physical presence to share with future generations-and e-books do not have a physical presence or, at least, do not exhibit the kind of physicality that we are used to preserving. Levy and Mole's observation, "where the words of the book will be absolutely identical... with everything else," exposes the root of this particular anxiety. With rare books, the importance of the object (physical format) supersedes the value of text (ideative book). With e-books, physical form is irrelevant, in some cases, to the text. It becomes much easier for book historians to discuss e-books than it does for libraries to preserve them.

The core problems of preserving digital materials is something archives have struggled with for years, but Joseph Williams and Elizabeth Berilla note that there are more problems involved with building a new digital collection than there are maintaining an existing digital collection: "Quickly antiquated technology, data redundancy, selection criteria, access issues (virtual, physical, and temporal)... and funding all contribute to the difficulties of establishing a digital archives." 3 They conclude that digital curation can be just as expensive and time consuming as print curation, and it also requires a new set of skills that can cause smaller institutions a massive headache. While their argument centers around born-digital records, which have their own policy protections that are not applied to e-books, the ongoing evolution of e-book formatting causes many of the same problems that Williams and Berilla highlight.

The greatest skill shift from print materials to digital materials is the element of preservation; a stable environment addresses most of the obvious causes of noticeable damage to print materials, but this is not true for digital materials. Thomas Wilson explains,

It is useful to understand that digital preservation is a game of probabilities. The activities undertaken are done to reduce the likelihood that a given object will be

2. Michelle Levy and Tom Mole, "Chapter 5: Remediating," in The Broadview Introduction to Book History (Peterborough, ON: Broadview Press, 2017), 135.

3. Joseph A. Williams and Elizabeth M. Berilla, "Minutes, Migration, and Migraines: Establishing a Digital Archives at a Small Institution,” The American Archivist 78, no. 1 (2015): 87. 
lost or corrupted because of bit rot, nefarious actions, obsolescence, etc.... The goal is to perform certain sets of actions that together mitigate the risks associated with digital objects. ${ }^{4}$

Wilson explains that there are many misconceptions of what does and does not preserve a digital object, and that special collections professionals must readdress perceptions of digital preservation and divorce it from the ideals of print preservation to be truly successful. He specifically notes that, with digital materials, it is sometimes necessary to separate the philosophical issue of access from the practical issue of preservation. Digital objects are malleable enough to allow alternative levels of access to the original file that are not possible with physical objects. If a patron asks to see an author's papers, you either give them the papers, or you give them a surrogate, and those two levels of access provide vastly different experiences. Digital surrogates of already born-digital materials are much different, since the flexibility of format in both the original and surrogate materials allow the surrogate to provide patrons with a more accurate imitation of the original. Wilson concludes that accepting and implementing that difference is one of the ways archives can improve upon their digital preservation.

E-books offer their own specific set of complications - in both purchasing and preserving. EBSCO, as an e-book provider for academic libraries, explains that the relationship between purchaser and provider changes with e-books: "While preserving a purchased print book lies solely with the purchaser, e-books surface questions about the responsibilities of the e-book provider in ensuring that customers' digital purchases are available in perpetuity." EBSCO's statement offers promises of thirdparty partners to assist libraries with preservation of their e-books, and a constant vigilance in maintaining the correct technology to keep their e-books from being lost or corrupted. As a provider that specifically works with libraries on a regular basis, EBSCO offers a best-case scenario of a provider-purchaser relationship that protects the e-book files - but even their promises raise questions. When stating that digital files are "available in perpetuity," does that mean forever, like with print materials? Or just as long as the subscription is maintained? The vague nature of EBSCO's promises could cause future problems for collecting institutions, and licensing agreements from major e-book providers such as Amazon and Barnes \& Noble are even less clear on the role they are contractually willing to play in e-book preservation.

4. Thomas Wilson, "Rethinking Digital Preservation: Definitions, Models, and Requirements," Digital Library Perspectives 33, no. 2 (2017): 130.

5. "E-Book Preservation: EBSCO's Ongoing Commitment to Preservation and Access for Libraries," EBSCOpost online (November 29, 2017), https://www.ebsco.com/blog/article/ ebscos-commitment-toe-book-preservation-and-access-for-libraries. 
The Terms of Service for Barnes \& Noble's NOOK-platform e-books, for example, explain that "we grant you a limited, non-exclusive, revocable license to access and make personal, non-commercial use of the Digital Content... We reserve the right to modify or discontinue the offering of any Digital Content at any time." ${ }^{6}$ The company never offers a more specific explanation of how limited their e-book licenses are, what rights of preservation a subscriber holds, or if there are ways to negotiate a more permanent license for a library institution. The terms also never explain what reasons might cause the company to modify or discontinue e-book files and if any actions to cut down the need to modify content after purchase are being taken. The same is true for Amazon: the company strictly reminds customers that "Kindle Content is licensed, not sold, to you by the Content Provider,"” and yet Amazon offers no further explanation on what that license does and does not entail in terms of preservation or if they take any steps to preserve content from their servers. Purchasing e-books requires both explicit and implicit trust in the e-book provider, which can be riskier with some providers.

\section{Discussion}

Despite the fact that e-books are an essential milestone of 21st-century book history, collecting and preserving books in digital formats requires more than just recognition and desire. Digital archives and academic library e-book collections offer an example of the infrastructure that must be put in place to sustain collecting e-books. E-books challenge conventional notions of what a book is, what it means to preserve the original object, and how patron interaction with that original digital file "object" might change in the short term and certainly over the long term. The examples illustrate the need for e-book publishers, distributors, and libraries to clearly define the differences between digital materials and physical materials, as well as e-books and print books, and allow those differences to re-inform our role as stewards of these objects.

This is not the first time in the history of the book that the identity of the book has been tested, nor will it be the last. The definition of the book in special collections is still closely tied to its physicality, an attitude that stands as a hinderance to future e-book collections. Amaranth Borsuk offers a way for special collections libraries to expand the notion of the book: "we might examine the book as what scholar N. Katherine Hayles calls a 'material metaphor' through which we interface with language and which in turn alters how we can do so." ${ }^{\prime}$ This is not to say that Bor-

6. "NOOK Store Terms of Service," Barnes \& Noble online (May 24, 2018), https: / / www.barnesandnoble.com/h/nook-store-terms-of-service.

7. "Kindle Store Terms of Use," Amazon online (October 5, 2016), https://www.amazon.com/gp/ help/customer/ display.html?nodeId=201014950.

8. Amaranth Borsuk, "The Book as Interface," in The Book (Cambridge: Massachusetts Institute of Technology Press, 2018), 203. 
suk advocates valuing the text over the book; rather, she argues that, by even using the term e-book, we reveal the fact that the term book has come to signify content, precluding any objects that do not reveal content in a physical, written form. By expanding the special collections definition of the book to signify "material metaphor" instead of content, we open a space for e-books within our holdings and clarify how our other books "interface with language" and why they are important to preserve on their own terms.

To successfully integrate e-book materials into special collections, we must also revisit the balance between preservation and accessibility when it comes to the "original object." Wilson argues that the restructuring of this balance is essential to safely preserving digital materials:

While the reason for preservation may be for future access, mixing philosophical issues and technical architectures can lead to confusing outcomes and potentially compromise the integrity of a preservation archive. In practice, often the dissemination information package includes a digital object that is, in fact, different than the object in the archival information package (e.g., resolution and file type for an image object). ${ }^{9}$

Since digital materials are so malleable, it is easier to accurately replicate the experience of interacting with the original object with a digital facsimile of some kind. This is especially important with e-book files, since the original files must be mediated to be usable by humans and can be altered by publishers/distributors. In terms of future historical research, facsimile technologies might actually be better for patron use than the original object itself. It is more likely for a Kindle-surrogate application that mimics the experience of using an original Kindle device to be accessible to historians in 100 years than it is to expect a 20th-century Kindle to be in perfect working order. We exist in a world where technology and digital spaces change, expand, and become obsolete daily; and, to preserve the history of the book in the early 21 st century, we must accept the reality of technical limits and obsolescence and, as a discipline, learn to preserve and make digital book collections accessible in new ways.

\section{Conclusion}

Housing e-book collections in special collections institutions requires long-term and short-term strategies. The long-term strategies, while not as immediately useful, allow institutions to build an infrastructure that will preserve original e-book

9. Wilson, "Rethinking Digital Preservation: Definitions, Models, and Requirements," 132. 
files for as long as is possible. First, special collections professional associations might begin forming relationships with e-book providers to work through the terms of partnership to facilitate preservation and protect the original e-book files from future provider changes as much as possible. This is a long-term goal because negotiations with providers will take time, some more than others if they do not normally work with academic and public libraries. A specific library institution cooperative organization could play a vital role in discussions with e-book providers to develop consistency across institutions in e-book preservation strategies-something that is lacking in discussions of perpetual access to other digital materials. We will need to determine our preservation needs, communicate them clearly, and work with e-book providers to build a foundational relationship that will make permanent e-book preservation possible in the future.

This long-term goal is not the only way forward; and, although we have not yet discovered a solution to the preservation problems associated with e-books, there are several short-term ways in which special collections libraries can begin purchasing and using e-books right now. A small collection of e-books offers excellent tools for book history instruction. For most patrons, e-books are an otherwise transparent everyday fact of life. They offer an accessible way to ease into the greater history of the book by pointing out pieces of e-book technology and comparing and contrasting these well-known features with machine press books, medieval manuscripts, or any other iteration of the book an institution wishes to showcase. Working backward like this allows patrons to latch onto concepts they are already familiar with to help understand what they are unfamiliar with, and this process can make them more comfortable interacting with the older materials.

Additionally, e-books give special collections libraries the opportunity to teach classes to students outside the library while using library materials. While digital surrogates and specially curated print collections have also assisted librarians in bringing collections outside the library and into the community, e-books are more durable to environmental changes. Community demonstrations and exhibitions are a great way to make the library feel more accessible and open to those who would not normally feel comfortable walking through the doors. Using a combination of e-book collections and digital surrogates of print collections, special collections librarians can not only brag about what their institution has to offer; they can teach book history in any number of spaces with actual collections at their disposal.

But teaching is not the only way that special collections libraries use materials; any institution looking to maintain a collection of e-books should also consider investing in technology that would allow e-books to be dynamically integrated into exhibitions, not just sitting inside a case. Since e-book files are impermanent at the 
moment, it might not be the best decision to just leave a Kindle full of e-books to the mercy of patrons. In the short term, unmitigated access to the original files, and to the device itself, could cause irreparable damage. But display screens with interactive capabilities could offer stable surrogates of the e-book experience that would heighten any exhibition. As Anna Dysert, Sharon Rankin, and Darren N. Wagner conclude in their recent article "Touch Tables for Special Collections Libraries," using interactive digital technology special collections exhibitions allows librarians to "showcase more materials in an array of formats... display greater amounts of materials... allow for a greater range of curatorial choices, and engage viewers in new ways." ${ }^{10}$ Adding more patron interaction through e-book surrogate technology would create a more memorable, exciting experience for patrons without risking damage to library materials, e-books or otherwise.

Finally, something that special collections libraries can do in the short term with e-book collections is to use them to first develop and then teach primary source literacy skills for digital materials. Primary source literacy looks much different with e-books than it does with physical books, and it is not a skill that many librarians, or many patrons and scholars for that matter, are trained in. If we wish to take the position of e-books in the broader history of the book more seriously, we need to learn how to properly read and interact with these materials as primary source objects. ${ }^{11}$ If we take the time to familiarize ourselves with these primary source literacy skills now, in the long term, when we have a better infrastructure in place for long-term preservation and access to e-books, we can pass this knowledge on to our patrons to help them interact with these materials safely and effectively.

There are problems that must be addressed before permanent preservation and accessibility can be achieved for e-books, but special collections libraries can still begin curating and using e-book collections. To be successful as stewards of book history in the digital age, special collections institutions must begin incorporating short-term measures, and investigating our long-term goals, to create a stable infrastructure for future e-book collections.

10. Anna Dysert, Sharon Rankin, and Darren N. Wagner, "Touch Tables for Special Collections Libraries: Curators Creating User Experiences," RBM 19, no. 1 (2018), https://rbm.acrl.org/index.php/ $\mathrm{rbm} /$ article/view/16983/18725.

11. Matthew G. Kirschenbaum's new book offers an example of looking at e-books as primary source objects, and how the rules of bibliography must change to be able to do so. Matthew G. Kirschenbaum, Bitstreams: The Future of Digital Literary Digital Heritage (Philadelphia: University of Pennsylvania Press, 2021). 